УДК 57.018.6:633.12:631.811.98

doi: 10.25128/2078-2357.21.1-2.11

В. П. КАРПЕНКО, І. І. МОСТОВ'ЯК, А. А. ДАЦЕНКО, Р. М. ПРИТУЛЯК, О. І. ЗАБОЛОТНИЙ

Уманський національний університет садівництва

вул. Інститутська, 1, Умань, Черкаська область, 20300

e-mail: adatsienko3@gmail.com

\title{
ВМІСТ ФОТОСИНТЕТИЧНИХ ПІГМЕНТІВ У ЛИСТКАХ ГРЕЧКИ ЗА ДІЇ БІОЛОГІЧНИХ ПРЕПАРАТІВ
}

У статті представлено результати польового досліду з вивчення дії різних норм мікробного препарату Діазобактерин за різних способів використання регулятора росту рослин Радостим (обробка насіння перед сівбою та обприскування посівів) на вміст у листках гречки сорту Слена хлорофілів $a$ i $b$, ïх суми і каротиноїдів. Визначення фотосинтетичних пігментів проводили у відібраних зразках листків гречки в польових умовах у фазах галуження у рослин стебла і початку цвітіння за методикою, описаною В.Ф. Гавриленко і Т. В. Жигаловою 3 використанням спектрофотометра LEKI SS1104.

Встановлено, що вміст фотосинтетичних пігментів у листках гречки залежав від норм i способів застосування досліджуваних препаратів та фаз розвитку культури. Зокрема, показано, що за комплексного застосування для передпосівної обробки насіння суміші мікробного препарату Діазобактерин у нормі 200 мл на гектарну норму насіння з регулятором росту рослин Радостим у нормі 250 мл/т з наступним обприскуванням по даному фону посівів регулятором росту рослин Радостим у нормі 50 мл/га у листках гречки формується найвищий у порівнянні із контролем вміст хлорофілу $a$ (на $40 \%$ ), хлорофілу $b$ (на $15 \%$ ), суми хлорофілів а+b (на $33 \%$ ) i каротиноїдів (на $29 \%$ ).

Ключові слова: регулятор росту рослин, мікробний препарат, гречка, хлорофіл, каротиноїди.

Ріст і розвиток рослин є складним динамічним показником стану рослинного організму, що включає комплекс взаємопов' язаних фізіологічних і біохімічних процесів, серед яких головним $\epsilon$ фотосинтез [3].

Фотосинтез забезпечує утворення в рослинах органічної речовини і формування продуктивності посівів. Проте перебіг фотосинтетичних реакцій у рослинах залежить від вмісту і співвідношення у листках пластидних пігментів, зокрема - хлорофілу і каротиноїдів [5]. Фотокаталізаторна дія хлорофілу визначає інтенсивність фотосинтезу. Саме тому пігментний склад листків має вирішальне значення в реалізації біологічного потенціалу всіх без виключення сільськогосподарських культур.

Дослідження свідчать $[4,9,11,14,17]$, що формування пігментного комплексу рослин залежить від низки абіотичних та біотичних чинників, у тому числі й від застосування мінеральних добрив, засобів захисту рослин та рістстимулювальних і мікробних препаратів. Так, за даними досліджень В. В. Гангура та Л. Є. Єремко [3], передпосівна інокуляція насіння нуту мікробним препаратом Ризогумін на фоні внесення мінеральних добрив посилювала інтенсивність формування асиміляційної поверхні посівів і їх фотосинтетичної продуктивності. Зокрема, вміст хлорофілу $а$ в листках рослин перевищував контрольний варіант на 0,6-7,08 мг/Г сухої речовини, хлорофілу $b-$ на $7,93-8,55$ мг/г сухої речовини.

Використання препаратів біологічного походження посилює в рослинах проходження обмінних процесів, що супроводжується розвитком потужної надземної і підземної біомаси, формуванням оптимального фотосинтетичного апарату зі збільшеним вмістом у листках хлорофілу [6, 15, 19]. Так, за даними досліджень Ю. О. Черницького [16], обробка насіння пшениці озимої мікробним препаратом Хетомік сприяла збільшенню вмісту хлорофілу $a$ у листках рослин на 43-68 \%. Водночас, поєднання інкрустації насіння та обприскування посівів 
буряків цукрових сорту Носівський Кристаліном підвищувало сумарне накопичення хлорофілу у листках рослин порівняно з контролем на $69 \%$ [12].

Дослідженнями В. М. Гавія, О. Б. Кучменка [1] обгрунтовано ефективність передпосівної обробки насіння кукурудзи мікробним препаратом Поліміксобактерин, за якої вміст хлорофілів $a$ i $b$ у листках рослин перевищував показники контролю на $26,8 \%$ і 41,0 \% відповідно.

Зважаючи на це, метою нашої роботи було дослідити вміст у листках гречки фотосинтетичних пігментів за використання бактеріального препарату Діазобактерин i регулятора росту рослин Радостим, що розкриває можливість з'ясувати спрямованість проходження в рослинах фізіолого-біохімічних процесів, від яких напряму залежить синтез органічної речовини і формування продуктивності посівів.

\section{Матеріал і методи досліджень}

Матеріалами дослідження слугували: рослини гречки (Fagopyrum esculentum Moench.), підвиду vulgaris, сорт Єлена, що виведений у науково-дослідному Інституті круп'яних культур Подільської державної аграрно-технічної академії та рекомендований для вирощування у Лісостеповій зоні та Поліссі; мікробний препарат Діазобактерин (штами бактерій Azospirillum brasilense 18-2 i 410, титр бактерій - не менше 2 млрд КУО/г; виробник Інститут сільськогосподарської мікробіології та агропромислового виробництва НААН, Україна), і регулятор росту рослин Радостим (Емістим С - 0,3 г/л, калієва сіль альфа-нафтилоцтової кислоти - 1,0 мг/л та мікроелементи; виробник ДП «Міжвідомчий НТЦ Агробіотех», Україна).

Польові досліди закладали в умовах дослідного поля Уманського національного університету садівництва у триразовому повторенні систематичним методом. Грунт дослідних ділянок - чорнозем опідзолений малогумусний важкосуглинковий на лесі з вмістом в орному шарі гумусу - 3,5 \%, рухомих сполук фосфору і калію (за методом Чирикова) - 88 і 132 мг/кг відповідно, азоту легкогідролізованих сполук (за методом Корнфілда) - 103 мг/кг; $p H$ сол. 6,2; гідролітична кислотність - 2,26 мг-екв./100 г грунту [18]. Схема досліду включала варіанти без обробки насіння (контроль) та з обробкою насіння перед сівбою мікробним препаратом Діазобактерин у нормах 150, 175 і 200 мл на гектарну норму насіння окремо й сумісно із рістрегулятором Радостим у нормі 250 мл/т; на фоні застосування вищезгаданих препаратів посіви гречки у фазу появи першої пари справжніх листків обприскували Радостимом у нормі 250 мл/га.

Вміст у листках гречки хлорофілів $a$ і $b$, каротиноїдів визначали у фазах галуження стебла і початку цвітіння рослин у відібраних зразках листків у польових умовах за методиками, описаними В.Ф. Гавриленко i Т. В. Жигаловою [2] з використанням спектрофотометра LEKI SS1104. Оптичну густину витяжок встановлювали за довжини хвиль 662 нм, 644 нм і 440 нм. Концентрацію пігментів розраховували за рівняннями Хольм Веттштейна для 100\%-го ацетону [2]:

$\mathrm{C}_{\text {хл. } a \text {, мг } / л}=9,784 * \mathrm{D} 662-0,990 * \mathrm{D} 644$

$\mathrm{C}_{\text {хл. }, \text {, мг } / л}=21,426 * \mathrm{D} 644-4,650 * \mathrm{D} 662$

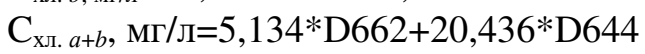

$\mathrm{C}_{\text {карот, мг/л }}=4,695 * \mathrm{D} 440,5-0,268 *\left(\mathrm{C}_{\text {хл. } .}+\mathrm{C}_{\text {хл. } .}\right)$

Далі розраховували вміст пігментів у рослинному матеріалі, мг/г сирої речовини:

$\mathrm{A}=(\mathrm{C} * \mathrm{~V}) /\left(\mathrm{H}^{*} 1000\right)$, де $\mathrm{C}-$ концентрація пігментів, мг/л,

$\mathrm{V}$ - об'єм екстракту, мл,

$\mathrm{H}$ - наважка рослинного матеріалу, г.

Статистичну оброку результатів досліджень виконували за методом дисперсійного аналізу, описаного Б. О. Доспєховим [7].

\section{Результати досліджень та їх обговорення}

Виконані дослідження показали, що вміст хлорофілів $a$ i $b$, ї суми і каротиноїдів у листках гречки у значній мірі залежав від норм використання мікробного препарату Діазобактерин і різних способів застосування регулятора росту рослин Радостим (табл. 1). 
Вміст хлорофілів $a$ і $b$, їх суми і каротиноїдів у листках гречки за дії Діазобактерину $\mathrm{i}$ Радостиму, середнє за 2017-2019 pр. (фаза галуження стебла, мг/г сирої речовини)

\begin{tabular}{|c|c|c|c|c|}
\hline \multirow{2}{*}{ Варіант досліду } & \multicolumn{2}{|c|}{ Хлорофіл } & \multirow{2}{*}{ Каротиноїди } \\
\cline { 2 - 4 } & $a$ & $b$ & $a+b$ & 0,45 \\
\hline Без застосування препаратів (контроль) & 0,92 & 0,38 & 1,30 & 0,47 \\
\hline Діазобактерин 150 мл & 1,02 & 0,41 & 1,43 & 0,47 \\
\hline Діазобактерин 175 мл & 1,03 & 0,41 & 1,44 & 0,48 \\
\hline Діазобактерин 200 мл & 1,06 & 0,42 & 1,48 & 0,46 \\
\hline Радостим 250 мл/т & 0,98 & 0,40 & 1,38 & 0,52 \\
\hline Діазобактерин 150 мл+Радостим, 250 мл/т & 1,10 & 0,46 & 1,56 & 0,53 \\
\hline Діазобактерин 175 мл+Радостим 250 мл/т & 1,12 & 0,47 & 1,59 & 0,53 \\
\hline Діазобактерин 200 мл+Радостим 250 мл/т & 1,14 & 0,48 & 1,62 & 0,48 \\
\hline Радостим 50 мл/га & 1,01 & 0,42 & 1,43 & 0,50 \\
\hline Діазобактерин 150 мл + Радостим 50 мл/га & 1,08 & 0,45 & 1,53 & 0,51 \\
\hline Діазобактерин 175 мл + Радостим 50 мл/га & 1,09 & 0,45 & 1,54 & 0,52 \\
\hline Діазобактерин 200 мл + Радостим 50 мл/га & 1,11 & 0,46 & 1,57 & 0,49 \\
\hline Радостим 250 мл/т + Радостим 50 мл/т & 1,04 & 0,43 & 1,47 & 0,56 \\
\hline Діазобактерин 150 мл + Радостим 250 мл/т + & 1,20 & 0,49 & 1,69 & 0,57 \\
\hline Радостим 50 мл/га & & & & 0,57 \\
\hline Діазобактерин 175 мл + Радостим 250 мл/т + & 1,22 & 0,49 & 1,70 & \\
\hline Радостим 50 мл/га & & & & $0,15-0,16$ \\
\hline Діазобактерин 200 мл + Радостим 250 мл/т + & 1,23 & 0,50 & 1,73 & \\
\hline Радостим 50 мл/га & & & & 0,15 \\
\hline НІР * & $0,16-0,17$ & $0,14-0,15$ & \\
\hline
\end{tabular}

Примітка: *- мінімальне та максимальне значення за роки досліджень.

Так, вміст хлорофілів $a$ i $b$ i їх суми за використання мікробного препарату Діазобактерин (обробка насіння перед сівбою у нормах 150, 175, 200 мл) у фазу галуження стебла перевищував контрольні показники на $0,1-0,14$ мг/Г сирої речовини для хлорофілу $a$, $0,03-0,04$ мг/г сирої речовини - $b, 1,13-1,18$ мг/г сирої речовини - суми хлорофілів $a+b$.

Активніше накопичення фотосинтетичних пігментів спостерігалося у варіантах, де для обробки насіння перед сівбою використовували суміш регулятора росту рослин Радостим i мікробного препарату Діазобактерин. Так, за такого поєднання препаратів вміст хлорофілу $a$ у листках гречки порівняно із контролем збільшувався на 19-24 \%, хлорофілу $b-$ на 21-26 \%, а суми хлорофілів $a+b-$ на 20-24\% відповідно. Використання мікробного препарату Діазобактерин у нормах 150, 175 і 200 мл для обробки насіння перед сівбою з наступним обприскуванням посівів регулятором росту рослин Радостим 50 мл/га забезпечило зростання вмісту хлорофілів відносно варіантів із самостійним внесенням Діазобактерину на 6-8 \% для хлорофілу $a ; 10-12 \%-b$ і 6-7 \% для суми хлорофілів $a+b$. Однак, найвищий вміст хлорофілів у листках гречки було встановлено за використання сумішей Діазобактерину (150, 175, 200 мл) з Радостимом (250 мл/т) для передпосівної обробки насіння наступним обприскуванням посівів Радостимом (50 мл/га), де перевищення до контролю складало 0,28-0,31 мг/г сирої речовини для хлорофілу $a, 0,11-0,12$ мг/г сирої речовини хлорофілу $b, 0,39-0,43$ мг/г сирої речовини - для суми хлорофілів $a+b$. Комбінована обробка насіння гречки сумішшю препаратів Діазобактерин і Радостим з наступним обприскуванням посівів Радостимом забезпечила зростання вмісту хлорофілів у порівнянні з варіантами обробки насіння перед сівбою сумішшю Діазобактерину і Радостиму на 8-9 \% для хлорофілу $a$, на 4-6\% хлорофілу $b, 6-8 \%$ - суми хлорофілів $a+b$. Одержані дані можуть свідчити, що інтродукція ризосферних мікроорганізмів із високою колонізаційною активністю у ризосферу гречки i стимулювальна дія екзогенних фітогормонів сприяють покращенню мінерального живлення рослин, що, у свою чергу, відображається на формуванні вмісту в рослинах фотосинтетичних пігментів. 
Щодо вмісту каротиноїдів у листках гречки, то в усіх варіантах досліду їх вміст перевищував контроль, а в варіантах Діазобактерин 150; 175 і 200 + Радостим 250 мл/т + Радостим 50 мл/га зазначений показник був найвищим і у відсотковому відношенні до контролю коливався на рівні 24-27 \%. Ці дані узгоджуються з даними вчених $[8,10]$, які також простежували зростання вмісту каротиноїдів у листках рослин під впливом біологічних препаратів, що може розглядатись як адаптивна ознака рослин у захисті реакційних центрів фотосистем від деструктивної дії активних форм кисню, які можуть утворюватися під впливом інтенсифікації обмінних процесів у рослинах. Зростання вмісту каротиноїдів у рослинах відіграє захисну роль у збереженні хлорофілів від фотоокиснення [13].

Аналіз вмісту хлорофілів і каротиноїдів у фазу початку цвітіння рослин гречки показав їх значне зростання у порівнянні з показниками у фазу галуження стебла, що може бути наслідком активізації проходження в рослинах фізіолого-біохімічних процесів на фоні покращення умов мінерального живлення рослин, процесів росту і розвитку рослин $[10,13]$. Так, вміст хлорофілів $a$ i $b$, їх суми та каротиноїдів за використання мікробного препарату Діазобактерин у нормах 150, 175 і 200 мл для обробки насіння перед сівбою перевищував контроль на 4-6 \% для хлорофілу $a, 2-3 \%$ - хлорофілу $b, 3-5 \%$ - суми хлорофілу $a+b$ та на 6$7 \%$ - для каротиноїдів (табл. 2).

За сумісного застосування мікробного препарату Діазобактерин у нормах 150, 175 і 200 мл і регулятора росту рослин Радостим у нормі 250 - для обробки насіння перед сівбою вміст хлорофілів $a$ i $b$, їх суми і каротиноїдів із наростанням норми внесення Діазобактерину зростав і перевищував контроль у межах 29-31 \% - для хлорофілу $a ; 10-11 \%$ - хлорофілу $b ; 24-26 \%$ ix суми та 23-24\% - для каротиноїдів. Найвищий вміст фотосинтетичних пігментів формувався в листках гречки за обробки посівів Радостимом у нормі 50 г/га на фоні використання Діазобактерину в нормі 200 мл з регулятором росту рослин Радостим у нормі 250 мл/т для обробки насіння, де перевищення до контролю складало 38-40 \% для хлорофілу $a$; 14-15 \% - хлорофілу $b$; 31-33 \% - суми хлорофілів $a+b$ та 27-29 \% - для каротиноїдів.

Таблиия 2

Вміст хлорофілів $a$ i $b$, їх суми і каротиноїдів у листках гречки за дії Діазобактерину і

Радостиму, середнє за 2017-2019 pр. (фаза початок цвітіння, мг/Г сирої речовини)

\begin{tabular}{|c|c|c|c|c|}
\hline \multirow{2}{*}{ Варіант досліду } & \multicolumn{3}{|c|}{ Хлорофіл } & \multirow{2}{*}{ Каротиноїди } \\
\cline { 2 - 4 } & $a$ & $b$ & $a+b$ & \\
\hline Без застосування препаратів (контроль) & 1,83 & 0,71 & 2,54 & 0,88 \\
\hline Діазобактерин 150 мл & 1,90 & 0,72 & 2,62 & 0,93 \\
\hline Діазобактерин 175 мл & 1,92 & 0,72 & 2,64 & 0,94 \\
\hline Діазобактерин 200 мл & 1,93 & 0,73 & 2,66 & 0,94 \\
\hline Радостим 250 мл/т & 1,86 & 0,71 & 2,57 & 0,92 \\
\hline Діазобактерин 150 мл+Радостим, 250 мл/т & 2,37 & 0,78 & 3,15 & 1,08 \\
\hline Діазобактерин 175 мл+Радостим 250 мл/т & 2,39 & 0,79 & 3,18 & 1,08 \\
\hline Діазобактерин 200 мл+Радостим 250 мл/т & 2,40 & 0,79 & 3,19 & 1,09 \\
\hline Радостим 50 мл/га & 1,99 & 0,71 & 2,70 & 0,93 \\
\hline Діазобактерин 150 мл + Радостим 50 мл/га & 2,24 & 0,73 & 2,97 & 1,05 \\
\hline Діазобактерин 175 мл + Радостим 50 мл/га & 2,32 & 0,73 & 3,05 & 1,06 \\
\hline Діазобактерин 200 мл + Радостим 50 мл/га & 2,37 & 0,74 & 3,11 & 1,06 \\
\hline Радостим 250 мл/т + Радостим 50 мл/т & 2,08 & 0,72 & 2,80 & 0,97 \\
\hline Діазобактерин 150 мл + Радостим 250 мл/т + \\
Радостим 50 мл/га & 2,53 & 0,81 & 3,34 & 1,12 \\
\hline Діазобактерин 175 мл + Радостим 250 мл/т + & 2,55 & 0,82 & 3,37 & 1,13 \\
\hline Радостим 50 мл/га & & & & 1,14 \\
\hline Діазобактерин 200 мл + Радостим 250 мл/т + & 2,56 & 0,82 & 3,38 & \\
\hline Радостим 50 мл/га & & & & $0,16-0,17$ \\
\hline НІР о5* & $0,18-0,19$ & $0,17-0,18$ & & \\
\hline
\end{tabular}

Примітка: * - мінімальне та максимальне значення за роки досліджень. 


\section{Висновки}

Сумісне використання мікробного препарату Діазобактерин та регулятора росту рослин Радостим для обробки насіння перед сівбою з наступним обприскуванням посівів Радостимом забезпечує зростання вмісту хлорофілів $a$ і $b$, їх суми і каротиноїдів у пігментному комплексі листків гречки. У варіантах сумісного застосування Діазобактерину у нормі 200 мл і Радостиму у нормі 250 мл/т для обробки насіння та обприскування по даному фону посівів Радостимом у нормі 50 мл/га в рослинах гречки формується найвищий вміст хлорофілу $a$, який у середньому за двома фазами росту і розвитку рослин перевищує контроль на $30-40 \%$; хлорофілу $b-15-$ $31 \%$; суми хлорофілів $\mathrm{a}+b-30-33 \%$; каротиноїдів - 24-29\%. Ці дані свідчать про створення більш сприятливих умов для проходження в рослинах фізіолого-біохімічних процесів, у тому числі й фотосинтетичних, за безпосередньої позитивної дії яких формується функціонально активний пігментний комплекс литкового апарату гречки.

1. Гавій В. М., Кучменко О.Б., Терещенко О. О. Вплив біопрепарату Поліміксобактерин та імунопротектора BAI-SI на вміст фотосинтетичних пігментів і урожайність кукурудзи. Збірник наукових праиь УНУС. 2019. 95 (1). С. 65-75.

2. Гавриленко В.Ф., Жигалов Т. В., Ермакова И. П. Большой практикум по фотосинтезу. М. : «Академия», 2003. 256 с.

3. Гангур В. В., Сремко Д. С., Сокирко Д.П. Формування продуктивності нуту залежно від технологічних факторів в умовах Лівобережного Лісостепу України. Зернові культури. 2017. Том 1. № 2. C. 285-292.

4. Грицаєнко 3. М., Пономаренко С. П., Карпенко В. П., Леонтюк І. Б. Біологічно активні речовини в рослинництві. К. : ЗАТ «Ничлава», 2008. $352 \mathrm{c.}$

5. Гуляєв Б. І. Екофізіологія фотосинтезу: досягнення, стан та перспективи досліджень. Фізіологія рослин в Украӥні на межі тисячоліття: зб. наук. праць. К., 2001. Т. 1. С. 60-74.

6. Дорошенко О. Л., Фоміна В. Я. Формування фотосинтетичних показників різних за походженням сортів гречки в умовах західного Лісостепу. Наукові праиі біоенергетичних культур і иукрових буряків. 2014. Вип. 21. С. 67-72.

7. Доспехов Б. А. Методика полевого опыта. М. : Агропромиздат, 1985. 350 с.

8. Кавулич Я. 3., Кобилецька М. І., Терек О. І. Вплив саліцилової кислоти на пігментну систему рослин гречки за токсичного впливу кадмію хлориду. Вісник Львівського університету. 2016. 72. С. 210217.

9. Карпенко В. П., Коробко О. О. Вплив гербіциду і біологічних препаратів на фотосинтетичну продуктивність і врожайність нуту. Вісник аграрної науки Причорномор'я. 2018. Вип. 4. С. 48-54.

10. Карпенко В. П., Притуляк Р. М. Фізіологічні зміни у рослинах ячменю ярого за дії біологічно активних речовин. Вісник Уманського НУС. 2014. № 1. С. 60-65.

11. Карпенко В. П., Шутко С. С. Вміст хлорофілу і фотосинтетична продуктивність рослин соризу за використання гербіциду Пік 75 WG і регулятора росту рослин Регоплант. Збірник наукових праць УНУС. 2018. 93 (1). C. 23-32.

12. Приплавко С. О. Залежність окремих фізіологічних процесів i продуктивності сільськогосподарських культур від дії металовмісних синтетичних регуляторів росту рослин : автореф. дис. на здобуття наук. ступеня канд. с.-г. наук: 03.00.12. Умань. 2008. 21 с.

13. Прядкіна Г. О., Маслюківська О. В., Стасик О. О., Оксьом В. П. Зв’язок вмісту хлорофілу в листках і хлорофільного індексу посівів озимої пшениці в період наливання зерна з урожайністю. Физиология растений и генетика. 2015. Т. 47. № 2. С. 167-174.

14. Романчук Л.Д., Зінченко О.В. Оцінка впливу регуляторів росту рослин на інтенсивність фотосинтезу, приживаність, морфологічні показники міскантусу гігантеусу. Наукові праиі інституту біоенергетичних культур і иукрових буряків. 2013. № 19. С. 47-51.

15. Сиваш О. О., Михайленко М. Ф., Золотарьова О. К. Варіація співвідношення вмісту хлорофілів а і b при адаптації рослин до зовнішніх чинників. Вісник Харківського національного аграрного університету. Серія біологія. 2018.3 (45). С. 49-73.

16. Черницький Ю. О. Вплив мікробіологічних препаратів на вміст хлорофілу в листках озимої пшениці. Сільськогосподарська мікробіологія. 2006. Вип. 4. С. 196-200.

17. Elkoca E., Kantar F., Fikrettin S., Influence of Nitrogen Fixing and Phosphorus Solubilizing Bacteria on the Nodulation, Plant Growth, Yield of Chickpea. Journal of Plant nutrition. 2008. 31. 157-171. 
18. Poltoretskyi S. P. Formation of density of sowing of millet (Panicum miliaceum L.) depending on the term and method of sowing. Bulletin of Uman NUH. № 1. 2017. P. 59-64.

19. Tatar O., Ozalkan C., Atasoy G. Partitioning of dry matter, proline accumulation,chlorophyll content and antioxidant activity of chickpea (Cicer arietinum L.) plants under chilling stress. Bulgarian Journal of Agricultural Science. 2013. № 19. C. 260-265.

\section{References}

1. Havii V. M., Kuchmenko O. B., Tereshchenko O. O. Vplyv biopreparatu Polimiksobakteryn ta imunoprotektora BAI-SI na vmist fotosyntetychnykh pihmentiv i urozhainist kukurudzy. Zbirnyk naukovykh prats UNUS. 2019. 95 (1). S. 65-75. [in Ukrainian]

2. Havrylenko V. F., Zhyhalov T. V., Ermakova Y. P. Bolshoi praktykum po fotosyntezu. M. : «Akademyia», 2003. 256 s. [in Russian]

3. Hanhur V. V., Yeremko D. S., Sokyrko D. P. Formuvannia produktyvnosti nutu zalezhno vid tekhnolohichnykh faktoriv v umovakh Livoberezhnoho Lisostepu Ukrainy. Zernovi kultury. 2017. Tom 1. № 2. S. 285-292. [in Ukrainian]

4. Hrytsaienko Z. M., Ponomarenko S. P., Karpenko V. P., Leontiuk I. B. Biolohichno aktyvni rechovyny v roslynnytstvi. K. : ZAT «Nychlava». 2008. 352 s. [in Ukrainian]

5. Huliaiev B. I. Ekofiziolohiia fotosyntezu: dosiahnennia, stan ta perspektyvy doslidzhen. Fiziolohiia roslyn $v$ Ukraini na mezhi tysiacholittia: Zb. nauk. prats. K., 2001. T. 1. S. 60-74. [in Ukrainian]

6. Doroshenko O. L., Fomina V. Ya. Formuvannia fotosyntetychnykh pokaznykiv riznykh za pokhodzhenniam sortiv hrechky v umovakh zakhidnoho Lisostepu. Naukovi pratsi bioenerhetychnykh kultur $i$ tsukrovykh buriakiv. Vyp. 21. 2014 r. S. 67-72. [in Ukrainian]

7. Dospekhov V. A. Metodyka polevoho opыta. Moskva. Ahropromyzdat. 1985. 350 s. [in Russian]

8. Kavulych Ya. Z., Kobyletska M. I., Terek O. I. Vplyv salitsylovoi kysloty na pihmentnu systemu roslyn hrechky za toksychnoho vplyvu kadmiiu khlorydu. Visnyk Lvivskoho universytetu. 2016. 72. S. $210-217$. [in Ukrainian]

9. Karpenko V.P., Korobko O. O. Vplyv herbitsydu i biolohichnykh preparativ na fotosyntetychnu produktyvnist i vrozhainist nutu. Visnyk ahrarnoi nauky Prychornomoria. 2018. Vyp. 4. S. 48-54. [in Ukrainian]

10. Karpenko V. P., Prytuliak R. M. Fiziolohichni zminy u roslynakh yachmeniu yaroho za dii biolohichno aktyvnykh rechovyn. Visnyk Umanskoho NUS. 2014. № 1. S. 60-65. [in Ukrainian]

11. Karpenko V.P., Shutko S.S. Vmist khlorofilu i fotosyntetychna produktyvnist roslyn sorytu za vykorystannia herbitsydu Pik 75 WG i rehuliatora rostu roslyn Rehoplant. Zbirnyk naukovykh prats UNUS. 2018. 93 (1). S. 23-32. [in Ukrainian]

12. Pryplavko S. O. Zalezhnist okremykh fiziolohichnykh protsesiv i produktyvnosti silskohospodarskykh kultur vid dii metalovmisnykh syntetychnykh rehuliatoriv rostu roslyn : avtoref. dys... kand. s.-h. nauk: 03.00.12. Uman. 2008. 21 s. [in Ukrainian]

13. Priadkina H. O., Masliukivska O. V., Stasyk O. O., Oksom V. P. Zviazok vmistu khlorofilu v lystkakh i khlorofilnoho indeksu posiviv ozymoi pshenytsi v period nalyvannia zerna $\mathrm{z}$ urozhainistiu. Fyzyolohyia rastenyi y henetyka. 2015. T . 47. № 2. S. 167-174. [in Ukrainian]

14. Romanchuk L. D., Zinchenko O. V. Otsinka vplyvu rehuliatoriv rostu roslyn na intensyvnist fotosyntezu, pryzhyvanist, morfolohichni pokaznyky miskantusu hihanteusu. Naukovi pratsi instytutu bioenerhetychnykh kultur i tsukrovykh buriakiv. 2013. № 19. S. 47-51. [in Ukrainian]

15. Syvash O. O., Mykhailenko M. F., Zolotarova O. K. Variatsiia spivvidnoshennia vmistu khlorofiliv a i b pry adaptatsii roslyn do zovnishnikh chynnykiv. Visnyk Kharkivskoho natsionalnoho ahrarnoho universytetu. Seriia biolohiia. 2018. 3 (45). S. 49-73. [in Ukrainian]

16. Chernytskyi Yu. O. Vplyv mikrobiolohichnykh preparativ na vmist khlorofilu v lystkakh ozymoi pshenytsi. Silskohospodarska mikrobiolohiia. 2006. Vyp. 4. S. 196-200. [in Ukrainian]

17. Elkoca E., Kantar F., Fikrettin S., Influence of Nitrogen Fixing and Phosphorus Solubilizing Bacteria on the Nodulation, Plant Growth, Yield of Chickpea. Journal of Plant nutrition. 2008. 31. 157-171.

18. Poltoretskyi S. P. Formation of density of sowing of millet (Panicum miliaceum L.) depending on the term and method of sowing. Bulletin of Uman NUH. № 1. 2017. R. 59-64.

19. Tatar O., Ozalkan C., Atasoy G. Partitioning of dry matter, proline accumulation,chlorophyll content and antioxidant activity of chickpea (Cicer arietinum L.) plants under chilling stress. Bulgarian Journal of Agricultural Science. 2013. № 19. S. 260-265. 
V. P. Karpenko, I. I. Mostoviak, A. A. Datsenko, R. M. Prytuliak, O. I. Zabolotnyi

Uman National University of Horticulture, Ukraine

Institutska St., 1, Uman, Cherkasy region, 20300

e-mail: adatsienko3@gmail.com

\section{THE CONTENT OF PHOTOSYNTHETIC PIGMENTS IN BUCKWHEET LEAVES UNDER THE INFLUENCE OF BIOLOGICAL PREPARATIONS}

The article presents the results of a field experiment to study the effects of different rates of the microbial preparation Diazobacterin under different methods of using the plant growth regulator Radostim (seed treatment before sowing and spraying crops) on the content of chlorophyll $a$ and $b$ in buckwheat leaves of Yelena variety, their sum and carotenoids.

Determination of chlorophyll a and b, their sum and carotenoids was performed in selected samples of buckwheat leaves in the field conditions, in the phases of stem branching and the beginning of flowering according to the method described by V.F. Gavrylenko and T.V. Zhyhalova using a spectrophotometer. The pigment concentration was calculated from Holm-Wettstein's equations for $100 \%$ acetone.

It was found that the content of photosynthetic pigments in buckwheat leaves is conditioned by the weather, rates and methods of application of the studied microbial preparations and phases of plant development. In particular, the analysis of chlorophyll and carotenoid content in the early flowering phase of buckwheat plants showed a significant increase compared to the phase of stem branching, which may be due to increased physiological and biochemical processes in plants, against the background of improving mineral nutrition, growth and plant development. Thus, with the multiple use of the microbial preparation Diazobacterin in the rates of 150, 175 and $200 \mathrm{ml}$ and the stimulator of plant growth Radostim in the rate of $250 \mathrm{ml} / \mathrm{t}$ for seed treatment before sowing, the content of chlorophylls $\mathrm{a}$ and $\mathrm{b}$, their sum and carotenoids with increasing application of Diazobacterin increased and the excess relative to control ranged within: 29-31\% for chlorophyll a; $10-11 \%$ for chlorophyll b; 24-26\% for their sum and 23-24\% for carotenoids.

At the same time, with a complex application for pre-sowing seed treatment of a mixture of the microbial preparation Diazobacterin in the rate of $200 \mathrm{ml}$ per hectare of seeds with the stimulator of plant growth Radostym in the rate of $250 \mathrm{ml} / \mathrm{t}$ followed by spraying on this background crops the stimulator of plant growth Radostim in the rate of $50 \mathrm{ml} /$ ha buckwheat leaves form the highest content of chlorophyll a in comparison with the control (40\%); chlorophyll b (15\%); the sum of chlorophyll $\mathrm{a}+\mathrm{b}(33 \%)$ and carotenoids $(29 \%)$.

These data indicate the creation of more favorable conditions for physiological and biochemical processes in plants, including photosynthesis, with the direct positive effect of which, functionally active pigment complex of the leaf apparatus of buckwheat is formed.

Keywords: stimulator of plant growth, microbial preparation, buckwheat, chlorophyll, carotenoids.

Надійшла 30.03.2021. 